\title{
First record of the razorbelly scad Alepes kleinii (Bloch, 1793) (Carangidae) along the coast of Bangladesh
}

\author{
Muhammad A. B. Siddik ${ }^{1 *}$ D, Md Abu Hanif ${ }^{1}$, Ashfaqun Nahar ${ }^{2},{\text { Md Reaz } \text { Chaklader }^{1} \text { and Rowan Kleindienst }}^{3}$
}

\begin{abstract}
Background: The Bay of Bengal coast, Bangladesh is a hotspot of fisheries abundance and diversity. A new species of Carangid family Alepes kleinii is recorded and described for the first time in the coastal waters of Bangladesh.

Results: A total of 29 individuals of Alepes kleinii were collected from the surveyed areas between January to March, 2016. Validation of this species was confirmed by phenotypic characteristics including body and fins colour, shape, vertical stripes, number of fin rays etc. which were found to be identical to that of the Alepes kleinii described in existing literature. The regression parameter value $(b=2.81)$ of the length-weight relationship $\left(W=a L^{b}\right)$ indicates that the Bay of Bengal provides favourable environmental conditions for the growth and development of this species.

Conclusion: The discovery of the razorbelly scad in these waters provide valuable information regarding species distribution and extension, location and habitat preference. This information is prerequisite for the sound management of the coastal fisheries of Bangladesh.
\end{abstract}

Keywords: Razorbelly scad, First record, Length weight relationship, Bay of Bengal coast, Bangladesh

\section{Background}

The razorbelly scad, Alepes kleinii (Bloch, 1793) is a reef associated, tropical marine fish species of the family Carangidae (Jack family).The dorsal surface of the Alepes kleinii is generally bluish grey to greenish grey, while ventral surface is lighter and more silvery in live specimens. In some specimens, dark vertical stripes are present above the lateral line and the presence of a large black spot on the upper operculum is also a key characteristic when identifying this species. The majority of the fins are transparent to pale in colour, with the caudal fin being predominantly yellowish. The razorbelly scad has predatory habits and generally preys upon small crustaceans, copepods, larval fish, lucifer shrimp, prawns, amphipods and fish eggs (Kalita \& Jayabalan, 2000). It is widely dispersed throughout the Mediterranean Sea and Red Sea in the west (Adam, 1966), and most of the Indo-West Pacific region including the coast of Pakistan, south-eastern coast of India, Sri Lanka, Indonesia, Philippines, Taiwan, Papua

\footnotetext{
*Correspondence: siddik@pstu.ac.bd

'Department of Fisheries Biology and Genetics, Patuakhali Science and

Technology University, Patuakhali 8602, Bangladesh

Full list of author information is available at the end of the article
}

New Guinea, Japan and northern Australia (Froese \& Pauly, 2016). Although wide-ranging coast of Bangladesh is regarded as fisheries biodiversity hotspot (Chaklader et al., 2015; Hanif et al. 2015; Siddik et al. 2015; Chaklader et al. 2016; Siddik et al. 2016a; Siddik et al., 2017) but until this record, the razorbelly scad has previously been unreported in Bangladesh.

Therefore, this present study reports the occurrence of Alepes kleinii in the southwestern coastal waters of Bangladesh. This will represent the first record of a new species of the Carangidae family in this region, adding to the increasing list of carangid fishes inhabiting the fringes of coastal Bangladesh.

\section{Methods}

During a 3 month survey of the diversity of fish species in

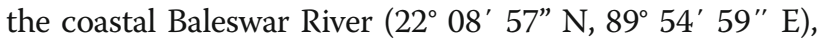

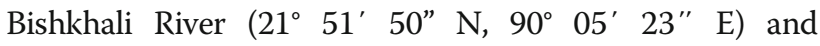
Burishwar River (21 $54^{\prime} 42^{\prime \prime} \mathrm{N}, 90^{\circ} 22^{\prime} 14^{\prime \prime}$ E) from January to March, 2016 of southern Bangladesh, a total of 29 specimens of Alepes kleinii were collected by artisanal fishermen using gillnets. The fish were sourced from local markets within close vicinity of the aforementioned rivers. 
A typical sample of collected Alepes kleinii and its global distributed areas including Bangladesh are shown in Fig. 1 and Fig. 2, respectively. The captured specimens were preserved and transported to the laboratory for identification, morphometric measurements and meristic counts were conducted following standard methods. All morphometric measurements were recorded in centimeters $(\mathrm{cm})$ taken with digital calipers and the weight of the fish samples were recorded to the nearest $0.01 \mathrm{~g}$ using digital electronic weighing balance (Shimadzu, EB-430DW, Japan).The length-weight relationship was calculated using the formula proposed by Ricker (1975) as:

$$
W=a L^{b}
$$

Where, $W$ is the weight of fish and $L$ is the total length of specimen, $a$ and $b$ are the regression parameters of length weight relationship.

\section{Results}

A total of 29 specimens of Alepes kleinii were collected from fishermen's catches for a period of three months from January to March, 2016 and identified as Alepes kleinii by a combination of characteristics using FishBase. Parameters used for identification included body colour (above and below lateral line), dark vertical strip, colour of caudal fin, black spot on operculum, number of dorsal fin, ventral spine, shape of caudal lobe, number of fin rays, strongly arched lateral line. The total length of collected specimens ranged from 8.6 to $15.8 \mathrm{~cm}$ and body weights varied between 9.61 to $51.47 \mathrm{~g}$. All morphometric measurements and meristic counts recorded from the specimens are presented in Table 1 . The results of length weight relationship are presented in Fig. 3.

\section{Systematics}

Order: Perciformes (Bleeker, 1859).

Family: Carangidae (Rafinesque, 1815).

Genus: Alepes (Swainson, 1839).

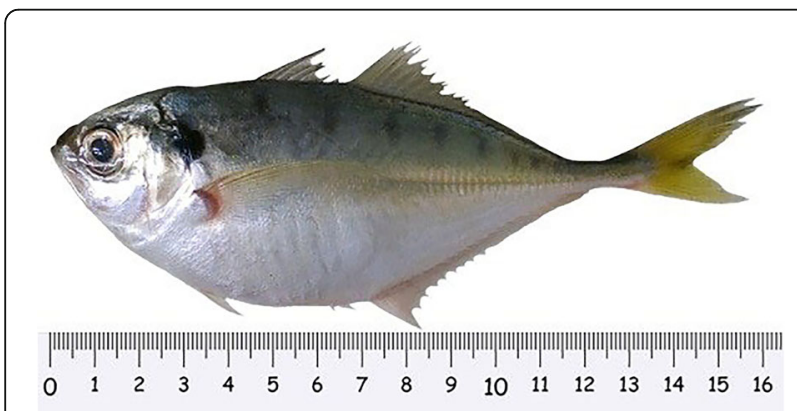

Fig. 1 Razorbelly scad Alepes kleinii (Bloch, 1793) collected from the southern coast of Bangladesh

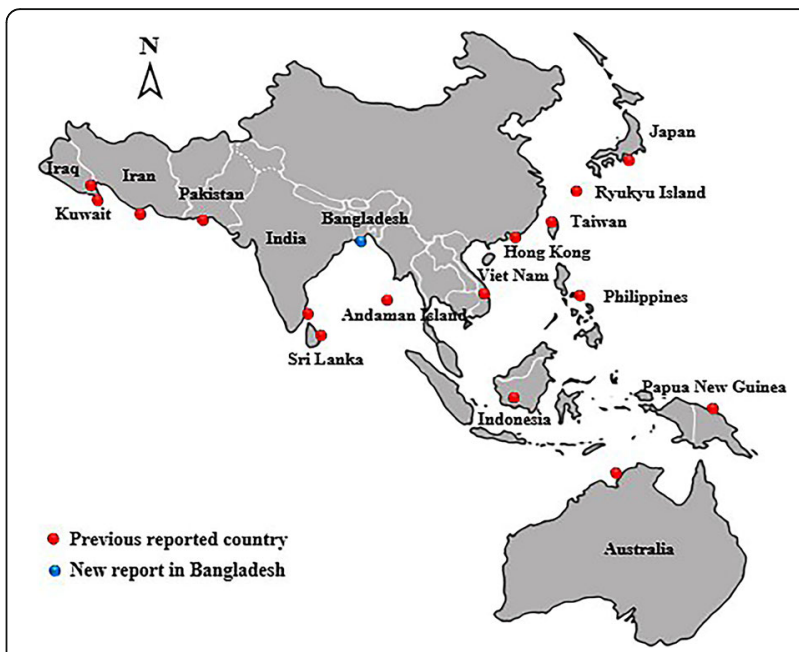

Fig. 2 Global distribution of Razorbelly scad, Alepes kleinii (Bloch, 1793) including newly report in Bangladesh

Alepes kleinii (Bloch, 1793).

Common name: Razorbelly scad (English), Macarela bandoneada (Spanish).

\section{Discussion}

The minimum and maximum fork length (FL) of 29 recorded individuals was $7.5 \mathrm{~cm}$ and $13.5 \mathrm{~cm}$ respectively, although Alepes kleinii can grow to a maximum $16 \mathrm{~cm}$ in length (FL) (Smith-Vaniz, 1984).The regression parameter $b$ of length weight relationship for Alepes kleinii $(b=2.81)$, was found to be within the expected normal range of $2.5<b<3.5$, as compared with the Bayesian LWRs predictions approach in FishBase (Froese, 2006; Siddik et al. 2016b; Islam et al. 2017; Hanif et al. 2017a). This indicates that this species will grow more in weight than in length and the coastal waters of Bangladesh are conducive for supporting the growth and development of this species.

Species distribution is influenced by a large number of environmental factors such as the geological history of the area, environmental stability, ecosystem productivity, habitat heterogeneity and suitability, and competition and predation (Legalle et al. 2008; Alshawy et al. 2016). Several vectors including patterns of water circulation, currents, and sea warming may provide suitable conditions for the expansion of its distribution range (Gurlek et al. 2016). Although, it is not exact whether the Alepes kleinii is endemic to the coastal Bangladesh region, or a recent migrant into these waters, despite the nearest reported findings being Sri Lanka (Robins et al. 1991) and South-East India (Kapoor et al. 2002). The authors agree with the proposition of Mahapatro et al. (2017), that fish always seek better environmental conditions can lead to alterations in geographical distribution. Furthermore, frequent climatic changes and human interventions have worked 
Table 1 Morphometric measurements and meristic counts of razorbelly scad, Alepes kleinii (Bloch, 1793) collected from the southern coast of Bangladesh $(n=29)$

\begin{tabular}{|c|c|c|c|c|}
\hline \multirow[t]{2}{*}{ Morphometric measurement } & \multirow[t]{2}{*}{ Acronym } & \multicolumn{2}{|c|}{ Length range $(\mathrm{cm})$} & \multirow[t]{2}{*}{ Mean \pm SD } \\
\hline & & Minimum & Maximum & \\
\hline Total length & $\mathrm{TL}$ & 8.6 & 15.8 & $11.3 \pm 1.76$ \\
\hline Fork length & $\mathrm{FL}$ & 7.9 & 13.5 & $9.8 \pm 1.47$ \\
\hline Standard length & SL & 7.2 & 11.8 & $9.3 \pm 1.13$ \\
\hline Body depth & $\mathrm{BD}$ & 3.9 & 4.9 & $4.4 \pm 0.30$ \\
\hline Caudal peduncle & $\mathrm{CP}$ & 0.4 & 0.6 & $0.5 \pm 0.01$ \\
\hline First pre-dorsal length & FPrDL & 3.1 & 4.2 & $3.6 \pm 0.21$ \\
\hline Second pre-dorsal length & SPrDL & 4.2 & 6.1 & $4.9 \pm 0.32$ \\
\hline Pre-pectoral length & PrPL & 2.2 & 3.4 & $2.6 \pm 0.11$ \\
\hline Pre-ventral length & PrVL & 1.9 & 4.1 & $2.9 \pm 0.14$ \\
\hline Pre-anal length & PrAL & 4.1 & 7.3 & $5.5 \pm 0.47$ \\
\hline Head length & $\mathrm{HL}$ & 1.7 & 3.2 & $2.4 \pm 0.09$ \\
\hline Pre-orbital length & PrOL & 0.4 & 0.7 & $0.5 \pm 0.01$ \\
\hline Orbital length & $\mathrm{OL}$ & 0.7 & 1.1 & $0.8 \pm 0.02$ \\
\hline Post-orbital length & PsOL & 0.6 & 1.4 & $0.9 \pm 0.04$ \\
\hline Meristic counts & & Minimum & Maximum & \\
\hline Number of first dorsal fin ray & FDFR & 7 & 8 & \\
\hline Number of second dorsal fin ray & SDFR & 23 & 24 & \\
\hline Number of pectoral fin ray & PFR & 21 & 22 & \\
\hline Number of ventral fin ray & VFR & 5 & 5 & \\
\hline Number of anal fin ray & AFR & 20 & 22 & \\
\hline Number of ventral spine & VS & 2 & 2 & \\
\hline
\end{tabular}

altogether to distribute species in new areas far from their natural habitat (Hanif et al. 2017b). Since the species have extended distribution throughout the Indo-West Pacific region, there is a possibility of climate changes led to a rise in the sea surface areas could have caused the fish dispersed from their native range to the coast of Bangladesh.

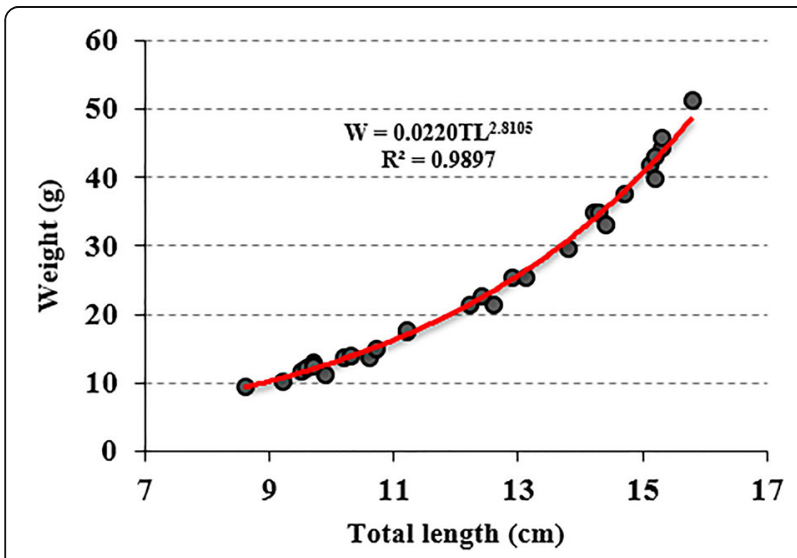

Fig. 3 Length-weight relationships of razorbelly scad, Alepes kleinii (Bloch, 1793) collected from southern coast, Bangladesh

\section{Conclusion}

According to the information collected through independent web-based search, the occurrence of razorbelly scad, Alepes kleinii is novel in the coastal region of Bangladesh. As the Alepes kleinii is within the same family as 37 other carangid species inhabiting southern Bangladesh, this particular fish has the potential to increase its range and adapt to the unique fisheries hotspot of southern coastal Bangladesh.

\section{Abbreviations}

AFR: Number of anal fin ray; BD: Body depth; CP: Caudal peduncle; FDFR: Number of first dorsal fin ray; FL: Fork length; FPrDL: First pre-dorsal length; HD: Head length; OL: Orbital length; PFR: Number of pectoral fin ray; PrAL: Pre-anal length; PrOL: Pre-orbital length; PrPL: Pre-pectoral length: PrVL: Pre-ventral length; PsOL: Post-orbital length; SD: Standard deviation; SDFR: Number of second dorsal fin ray; SL: Standard length; SPrDL: Second pre-dorsal length; TL: Total length; VFR: Number of ventral fin ray; VS: Number of ventral spine

\section{Acknowledgements}

The authors are indebted to fishermen helped in collecting fish specimens. We also highly thankful to Regional Horticulture Research Centre (RHRC) for providing lab facilities.

\section{Funding}

The present study was supported through MS fellowship from the Ministry of Science and Technology (NST-2014-2015), Government of the people's republic of Bangladesh. 


\section{Availability of data and materials}

All data generated during the study are interpreted in the manuscript.

\section{Authors' contributions}

MABS and MAH conceived of the study, carried out the identification of the specimens and drafted the manuscript. AN and MRC participated in its design, coordination and helped to drafted the manuscript, RK revised and finalised the manuscript. All authors read and approved the final manuscript.

\section{Ethics approval and consent to participate}

No specific ethical issues were required for the described study in Bangladesh.The sampling areas are not privately owned or protected and the study did not involve endangered or protected species.

\section{Consent for publication}

Not applicable.

\section{Competing interests}

The authors declare that they have no competing interests.

\section{Publisher's Note}

Springer Nature remains neutral with regard to jurisdictional claims in published maps and institutional affiliations.

\section{Author details}

'Department of Fisheries Biology and Genetics, Patuakhali Science and Technology University, Patuakhali 8602, Bangladesh. ${ }^{2}$ Department of Marine Fisheries and Oceanography, Patuakhali Science and Technology University, Patuakhali 8602, Bangladesh. ${ }^{3}$ Department of Environment and Agriculture, Curtin University, 1 Turner Avenue, Bentley, WA 6102, Australia.

Received: 6 March 2017 Accepted: 30 November 2017

Published online: 19 December 2017

\section{References}

Adam BT. "Red Sea fishes recently found in the Mediterranean".Copeia. ASIH. 1966;2:254-75.

Alshawy F, Lahlah M, Hussein C. First record of the Berber ponyfish Leiognathus berbis Valenciennes, 1835 (Osteichthyes: Leiognathidae) from Syrian marine waters (eastern Mediterranean). Mar Biodivers Rec. 2016;9:98.

Chaklader MR, Siddik MAB, Nahar A. Taxonomic diversity of Paradise threadfin Polynemus paradiseus (Linnaeus, 1758) inhabiting coastal rivers in Bangladesh. Sains Malaysiana, 2015; 44:1241-48.

Chaklader MR, Siddik MAB, Hanif MA, Nahar A, Sultan Mahmud S, Piria M. Morphometric and meristic variation of endangered pabda catfish Ompok pabda (Hamilton-Buchanan, 1822) from southern coastal waters of Bangladesh. Pakistan J Zool. 2016;48(2):233-40.

Froese R. Cube law, condition factor and weight-length relationships: history, meta-analysis and recommendations. J Appllchthyol. 2006;22(4):241-53.

Froese R, Pauly D. FishBase (wwwDatabase). World Wide Web electronic publication. 2016. Retrieved from http://www.fishbase.org/search.php. Electronic version; Accessed on 11 Jan 2016.

Gurlek M, Erguden D, Dogdu SA, Turan C. First record of greenback horse mackerel, Trachurus declivis (Jenyns, 1841) in the Mediterranean Sea. J Appl Ichthyol. 2016:32(5):976-7.

Hanif MA, Siddik MAB, Chaklader MR, Nahar A, Mahmud S. Fish diversity in the southern coastal waters of Bangladesh: present status, threats and conservation perspectives. Croat J Fisheries. 2015;73:148-61.

Hanif MA, Siddik MAB, Chaklader MR, Pham HD, Kleindienst R. Length-weight relationships of three catfish species from a tributary of the Dhaleshwari River, Bangladesh. J Appl Ichthyol. 2017a;33:1261-62. https://doi.org/10.1111/ jai.13448.

Hanif MA, Siddik MAB, Nahar A, Chaklader MR, Fotedar R. A new distribution of the buffon's river garfish, Zenarchopterus buffonis (Valenciennes, 1847) in the coastal rivers of Bangladesh. J Appl Ichthyol. 2017b;33:1211-14. https://doi. org/10.1111/jai.13462.

Islam MA, Siddik MAB, Hanif MA, Chaklader MR, Nahar A, Ilham I. Length-weight relationships of four small indigenous fish species from an inland artisanal fishery, Bangladesh. J Appl Ichthyol. 2017;33:851-2.
Kalita B, Jayabalan N. Food and feeding habits of the golden scadCaranxkalla (Cuv. \& Val.) along Mangalore coast. Environ Ecol. 2000;18(4):869-73.

Kapoor D, Dayal R, Ponniah AG. Fish biodiversity of India. India: National Bureau of Fish Genetic Resources Lucknow; 2002. p. 775.

Legalle M, Mastrorillo S, Céréghino R. Spatial distribution patterns and causes of decline of three freshwater species with different biological traits (white-clawed crayfish, bullhead, freshwater pearl mussel): a review. Ann Limnol-Int J Lim. 2008:44(2):95-104.

Mahapatro D, Mishra RK, Panda S. Range extension of a vulnerable sea horse Hippocampus fuscus (Actinopterygii: Syngnathidae) on the north-eastern bay of Bengal coast. Mar Biodivers Rec. 2017;10:6.

Ricker WE. Computation and interpretation of biological statistics of fish populations. J Fish Res Board Can. 1975;191:1-382.

Robins CR, Bailey RM, Bond CE, Brooker JR, Lachner EA, Lea RN, Scott WB. World fishes important to north Americans. Exclusive of species from the continental waters of the United States and Canada. Am Fish Soc. 1991;21:243.

Siddik MAB, Hanif MA, Chaklader MR, Nahar A, Mahmud S. Fishery biology of gangetic whiting Sillaginopsis panijus (Hamilton, 1822) endemic to Ganges delta, Bangladesh. Egypt J Aquat Res. 2015;41:307-13.

Siddik MAB, Hanif MA, Chaklader MR, Nahar A, Fotedar R. A multivariate morphometric investigation to delineate stock structure of gangetic whiting, Sillaginopsis panijus (Teleostei: Sillaginidae). Springer Plus. 2016a;5:520.

Siddik MAB, Chaklader MR, Hanif MA, Islam MA, Fotedar R. Length-weight relationships of four fish species from a coastal artisanal fishery, southern Bangladesh. J Appl Ichthyol. 2016b;32:1300-2.

Siddik MAB, Chaklader MR, Hanif MA, Nahar A, llham I, Cole A, Fotedar R. Variation in the life-history traits of a schilbid catfish, Clupisoma garua (Hamilton, 1822) in the coastal waters of southern Bangladesh. Chin J Oceanol Limnol, 2017; 35: 1189-1196.

Smith-Vaniz WF. Carangidae. In: Fischer W, Bianchi G, editors. FAO species identification sheets for fishery purposes, vol. 1. Rome: Western Indian Ocean fishing area, FAO; 1984. p. 51.

\section{Submit your next manuscript to BioMed Central and we will help you at every step:}

- We accept pre-submission inquiries

- Our selector tool helps you to find the most relevant journal

- We provide round the clock customer support

- Convenient online submission

- Thorough peer review

- Inclusion in PubMed and all major indexing services

- Maximum visibility for your research

Submit your manuscript at www.biomedcentral.com/submit
C Biomed Central 